\title{
ASTROGLIAL UPTAKE IS MODULATED BY EXTRACELLULAR $\mathrm{K}^{+}$
}

\author{
C. J. Cummins, ${ }^{1}$ R. A. Glover ${ }^{2}$ and O. Z. Sellinger ${ }^{3}$ \\ ${ }^{1}$ Department of Human Genetics, ${ }^{2}$ Department of Anatomy and ${ }^{3}$ Mental Health Research Institute, \\ The University of Michigan, Ann Arbor, MI 48109, U.S.A.
}

(Received 4 October 1978. Accepted 5 March 1979)

\begin{abstract}
Primary cultures of rat brain astrocytes were used to examine the uptake of the glucose analogue, 2-deoxy-d-glucose (2-DOG). 2-DOG competes with glucose for uptake, indicating that both are transported by the same carrier system. Extracellular $\mathrm{K}^{+}$at $11.9 \mathrm{~mm}$ increased the uptake of 2-DOG at 2-DOG concentrations greater than $100 \mu \mathrm{M}$. Uptake appears $\mathrm{Na}^{+}$-dependent only at high concentrations of 2-DOG. This suggests that the extracellular concentrations of $\mathrm{Na}^{+}$and $\mathrm{K}^{+}$may regulate the astrocytic uptake of 2-DOG.
\end{abstract}

THE REGULATION of glucose uptake in the nervous system is poorly understood. Glucose is virtually the sole carbon source for the adult mammalian brain (KETY, 1957; BALAZS, 1970). It is rapidly taken up both in vivo (KeTY, 1957; PARdRIDGe \& OldendorF, 1975) and in vitro (BACHELARD, 1971; HoRTON et al., 1973) and metabolized to amino acids, nucleic acids, and proteins (MAKER et al,, 1976). Glucose is transported into brain by either passive or facilitated diffusion (PARDRIDGe \& Oldendorf, 1975), but little is known about the mechanism of, or regulation of glucose uptake in the various cell types in brain.

The uptake of glucose may be the rate-limiting step in cerebral glycolytic metabolism (RoLlesToN \& NEWSHOLME, 1967; MAKER et al., 1976). It appears to be ion-dependent, requiring both $\mathrm{K}^{+}$and $\mathrm{Na}^{+}$ (SCHultz \& CURRAN, 1970). This implies that extracellular $\mathrm{K}^{+}$may act as a modulator of glucose uptake in vivo. The close apposition of neuronal and glial membranes (Peters \& PALAY, 1965) gives credence to this possibility. Extracellular $\mathrm{K}^{+}$may reach levels of $9-12 \mathrm{~mm}$ in the stimulated intact cat cortex, and at the upper limits of $\left[\mathrm{K}^{+}\right]_{\text {out }}$, glial membranes depolarize (SOMJen, 1975). Increased extracellular $\mathrm{K}^{+}$elevates the $\mathrm{O}_{2}$ consumption of brain slices (McILWAIN, 1951, 1953; Hertz \& Clausen, 1963), of hand dissected glia (HERTZ, 1966) and of cultured astrocytes (Hertz, 1973a, b; Hertz et al., 1973). Indeed, Hertz, $(1973 a, b)$ has suggested that astrocytes may be the cerebral cell type most affected by shifts in extracellu$\operatorname{lar} \mathrm{K}^{+}$

A technique for the culture of pure populations of non-neoplastic astrocytes (CUmmins \& GLOVER, 1978) has allowed us to explore the control of glucose uptake by $\mathrm{K}^{+}$. We demonstrate here that $\mathrm{K}^{+}$modulates the uptake of the glucose analog 2-deoxy- $d$ glucose (2-DOG) in astrocytes in vitro.

\section{MATERIALS AND METHODS}

The technique for culturing astrocytes from neonatal rat brain has been described elsewhere (CUMmins \& GLOver, 1978). Briefly, forebrains of 3-4-day-old neonatal rats were dissected under sterile conditions, minced and trypsinized in $0.25 \%$ trypsin in Earle's Balanced Salt Solution (BSS). The suspension was centrifuged, and the pellet was washed once in BSS, and diluted to yield $1060 \times 15 \mathrm{~mm}$ plates (3002 series, Faicon Plastics) per forebrain. Cells were grown in a medium composed of $10 \%$ fetal bovine serum in MEM, with either Earle's or Hank's BSS. The medium was supplemented with $100 \mathrm{U}$ penicillin, $100 \mu \mathrm{g}$ streptomycin, and $100 \mathrm{U}$ polymyxin per ml medium. Cells were grown in a National incubator, in an atmosphere of $95 \%$ air and $5 \% \mathrm{CO}_{2}$. Under these conditions, cells grew to confluency in 12-14 days. Glial specific stains were used to aid in identifying and characterizing the confluent cells (CUMmins \& Glover, 1978).

Radioactive 2-deoxy-d-glucose, $\left[{ }^{3} \mathrm{H}(\mathrm{G})\right]$, was obtained from New England Nuclear (Boston, MA) and had a specific activity of $10 \mathrm{Ci} / \mathrm{mmol}$. Crystalline 2-DOG was obtained from Sigma Chemical Co., and PL Biochemicals. The purity of both preparations was tested by tlc, and found to contain less than $1.0 \%$ glucose.

Uptake of 2-DOG was performed on confluent cultures 16-18 days after plating. Sixty millimeter Petri dishes (Falcon Ware, 3002 Series) were used routinely. Dishes were removed from the incubator, media poured off and the edges blotted. The plates were washed with $12-15 \mathrm{ml}$ of $0.9 \% \mathrm{NaCl}$ at room temperature, inverted, and blotted. Two milliliters of warm $\left(37^{\circ} \mathrm{C}\right)$ incubating solution containing the desired concentrations of 2-DOG and $\mathrm{K}^{+}$ions were added and the dishes incubated at $37^{\circ} \mathrm{C}$. At the indicated times, the incubation solution was poured off, and plates were rapidly washed 3 times each with approx $20 \mathrm{ml}$ of ice-cold $0.9 \% \mathrm{NaCl}$. Two milliliters of $0.4 \mathrm{~N}-\mathrm{NaOH}$ was immediately added to stop the uptake and digest the cell monolayer (KLetzien \& Purdue, 1974).

To determine non-specific binding of radioactive 2-DOG, fresh dishes were washed with ice cold $0.9 \% \mathrm{NaCl}$, 
and the edges blotted. Two milliliters ice-cold medium was added containing the appropriate concentration of 2-DOG and ions. The medium was rapidly swirled and poured off $(3-5 \mathrm{~s})$. Plates were washed again with ice-cold $0.9 \%$ $\mathrm{NaCl}$ and the cells digested in $\mathrm{NaOH}$. After 12-14 h at $4^{\circ} \mathrm{C}$, the cells were completely digested. An equal volume of $0.4 \mathrm{~N}-\mathrm{HCl}$ was added, and duplicate aliquots counted. Samples were corrected for quenching on the basis of internal standardization. Values for blanks were subtracted from each time point to give the indicated uptake.

To determine protein content, five culture dishes were taken from the same batch on the same day as the uptake experiments. Cells washed free of medium were homogenized, and the protein determined (LowRy et al., 1951).

Unless indicated otherwise, uptake of 2-DOG was measured in a medium of $5.3 \mathrm{mM}-\mathrm{KCl}, 150 \mathrm{~mm}-\mathrm{NaCl}$, $1.0 \mathrm{mM}^{-\mathrm{CaCl}_{2}}, \quad 600 \mu \mathrm{M}-\mathrm{MgCl}_{2}, \quad 1.6 \mathrm{mM}-\mathrm{KH}_{2} \mathrm{PO}_{4}$ and $4.3 \mathrm{mM}-\mathrm{Na}_{2} \mathrm{HPO}_{4}$. Final concentrations of each cation were 158.6 mequiv $/ . \mathrm{Na}^{+}$and 6.9 mequiv $/ 1 . \mathrm{K}^{+}$. When the ionic composition of the medium was varied, $\mathrm{Na}^{+}$was substituted for $\mathrm{K}^{+}$isoosmotically.

To determine the intracellular concentration of 2-DOG-6- $\mathrm{PO}_{4}$, an aliquot of cell extract was run on silica gel tlc plates in chloroform-methanol-water $(60: 70: 26)$. The dried plates were sprayed for reducing sugar (BLOCK et al., 1958) revealing two spots which were established to be 2-DOG and 2-DOG-6-PO 4 . Both spots were scraped from the plates and their radioactivity determined.

\section{RESULTS}

Confluent cells showed the characteristic morphology of astrocytes in vitro (SHEIN, 1965; NAKAI \& OKamoto, 1968; MurRay, 1968; Antanitus et al., 1975). The cells were flat, and possessed several processes but showed no obvious polarity. Nuclei were ovoid and contained one or two nucleoli.

When stained with glial specific stains, confluent cultures appear similar to astrocytes in vivo (Fig. 1). Staining was uniform and very few cells did not impregnate. Morphological, histological, and cytochemical characterization of cultured cells appear to indicate that our technique yields a homotypic population of astrocytes (Cummins \& GLOVER, 1978) (Fig. 1).

Since rapidly growing cultures take up sugar analogs more rapidly than confluent cultures (SEFTIN \& Rubin, 1971; Kletzien \& Purdue, 1974), uptake studies were always performed on cultures 16-18 days old, and fed $48 \mathrm{~h}$ prior to the experiments. A time course of the uptake of $2 \mathrm{~mm}-2-\mathrm{DOG}$ shows that it was linear for at least $15 \mathrm{~min}$ (Fig. 2).

Kinetic parameters of 2-DOG uptake were determined in media containing $0.1,0.25,0.5$ and $1.0 \mathrm{~mm}-2-\mathrm{DOG}$ in the presence and absence of $1.0 \mathrm{~mm}$-glucose, and after $15 \mathrm{~min}$ of incubation. A Lineweaver-Burk plot of 2-DOG uptake is shown in Fig. 3. A $K_{m}$ for the uptake of $0.37 \mathrm{~mm}$ was determined with a $V_{\max }$ of $189 \mathrm{nmol} / \mathrm{mg}$ protein $/ 15 \mathrm{~min}$. These values are lower than reported for $2-D O G$ uptake by non-nervous tissue (RENNER et al., 1972; Kletzien \& Purdue, 1974; Sandra \& Przybylski,

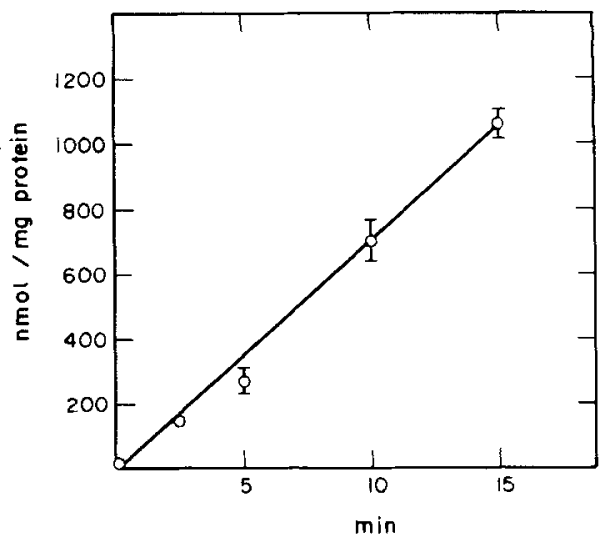

FIG. 2. Time course of 2-DOG uptake. Confluent cells were incubated for the indicated time in $2.0 \mathrm{~mm}-2-\mathrm{DOG}$, in a buffer containing $6.9 \mathrm{~mm}-\mathrm{K}^{+}$, and $158.6 \mathrm{~mm}-\mathrm{Na}^{+}$. The cells were washed at the end of the incubation, and digested with $0.4 \mathrm{~N}-\mathrm{NaOH}$, according to Materials and Methods. Duplicate aliquots from 3 to 5 plates were counted and averaged and the S.E.M. determined for each point. In this and the two following figures, only points with the S.E.M. greater than $10 \%$ will show error bars.

1975), lower than those reported for brain slices (BACHELARD, 1971) and whole brain (HORTON et al., 1973; PARdRIDGE \& OldENDORF, 1975), close to values reported for synaptosomes (DIAMOND \& FISHMAN, 1973).

2-DOG and glucose may be transported by the same carrier system (BIDDER, 1968; BACHELARD et al., 1971; Betz \& Gilboe, 1974). Glucose inhibition of 2-DOG uptake (BACHELARD, 1971; HoR TON et al., 1973; KoHN \& Clausen, 1972) is therefore evidence that the carrier systems are the same. Figure 3 also shows that $1.0 \mathrm{~mm}$-glucose competitively inhibited 2-DOG uptake. An apparent $K_{i}$ value of $3.3 \mathrm{~mm}$ was determined.

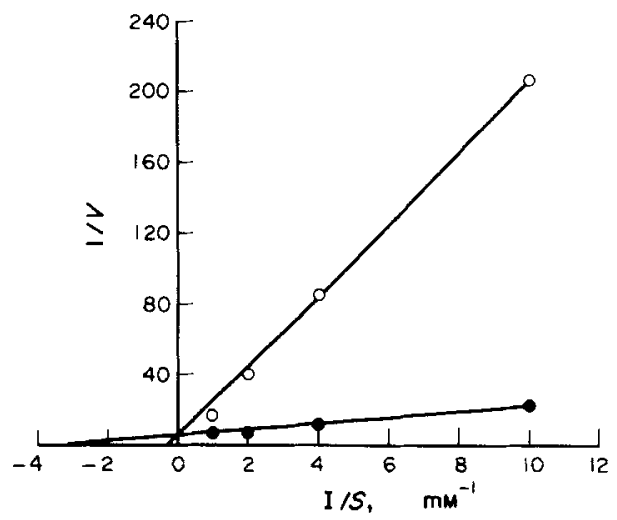

FIG. 3. Kinetics of 2-DOG uptake, and the competitive inhibition of 2-DOG uptake by glucose. 2-DOG at 0.10, $0.25,0.50$ and $1.00 \mathrm{~mm}$ was incubated with $(\mathrm{O}-\mathrm{O})$ or without $(-0) 1.0 \mathrm{~mm}$ glucose for $15 \mathrm{~min}$. Units: V, $\mu \mathrm{mol}$ 2-DOG taken up per $\mathrm{ml}$ protein in $15 \mathrm{~min}$ of incubation: S, mM. The $V_{\max }$ is $189 \mathrm{nmol} / \mathrm{mg}$ protein $\times 15 \mathrm{~min}$, and the apparent $K_{i}$ is $3.3 \mathrm{~mm}$. Each point represents duplicate determinations on 3-5 culture dishes. 


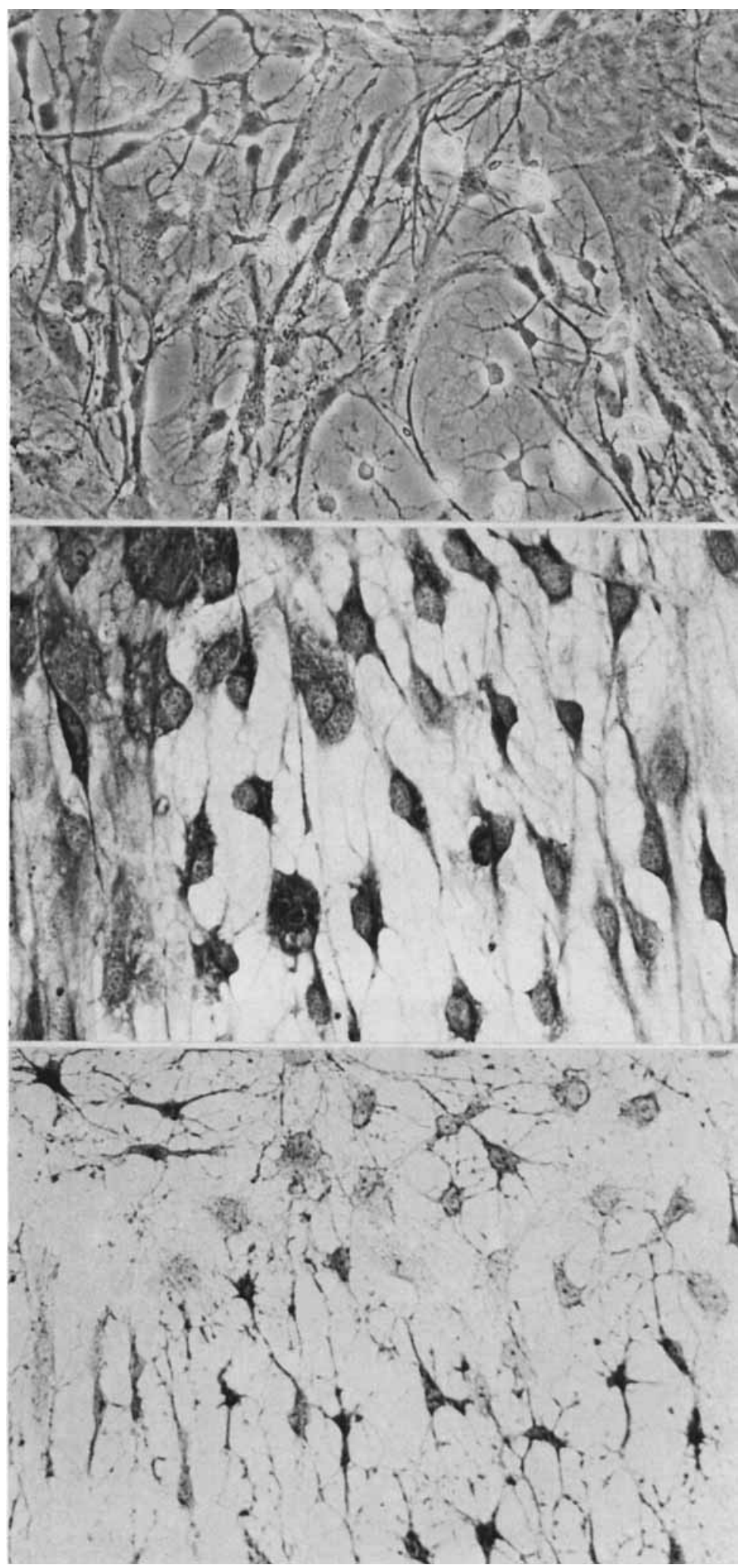

FiG. 1. Morphology and cytochemistry of cultivated astrocytes. Top: living cells, phase contrast photomicrograph, $200 \times$. Middle: confluent astrocytes stained with Mallory's phosphotungstic acid hematoxylin. For details, consult Cummins \& Glover (1978). Bottom: cells stained with Cajal's Gold Sublimate method. Astrocytes stain ubiquitously with this astrocyte specific stain. For details of this procedure, consult Cummins \& Glover (1978). 


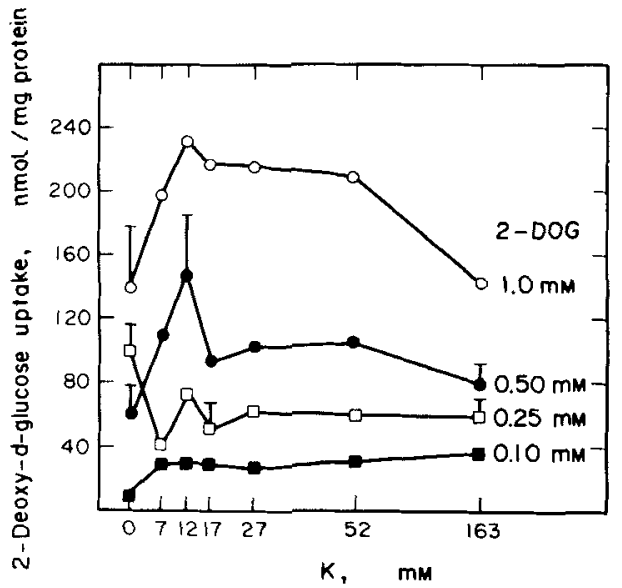

FIG. 4. Potassium-dependence of 2-DOG uptake. Cultures were incubated with the indicated concentration of 2-DOG for $15 \mathrm{~min}$. The final concentration of $\mathrm{NaCl}+\mathrm{KCl}$ was $163 \mathrm{~mm}$. To achieve the indicated concentration of $\mathrm{K}^{+}$, $\mathrm{KCl}$ was isoosmotically substituted for $\mathrm{NaCl}$. Each point represents the average of duplicate determinations on 3-5 dishes.

2-DOG uptake was examined under conditions of varying extracellular $\mathrm{K}^{+}$concentrations. When $\mathrm{Na}^{+}$ was replaced isoosmotically with $\mathrm{K}^{+}$, sugar uptake increased at 2-DOG concentrations greater than $100 \mu \mathrm{M}$, and reached a maximum at $11.9 \mathrm{~mm}-\mathrm{K}^{+}$. Increasing $\mathrm{K}^{+}$concentration had a mixed effect on 2-DOG uptake when compared to levels seen at $6.9 \mathrm{mM}-\mathrm{K}^{+}$. 2-DOG uptake was also examined in a $\mathrm{K}^{+}$and $\mathrm{Na}^{+}$free medium and found to be decreased at most 2-DOG concentrations as shown in Fig. 4.

In brain, 2-DOG is rapidly phosphorylated to 2-DOG-6-phosphate by hexokinase (DIAMOND \& Fishman, 1973). This phosphorylated form usually constitutes the preponderance of intracellular 2-DOG. HorToN et al. (1973) found that $2-\mathrm{DOG}-6-\mathrm{PO}_{4}$ constituted $60 \%$ of the total in a whole brain preparation, while Diamond \& FishmaN (1973) found the phosphorylated form to represent $77 \%$ of the total in a synaptosomal preparation.

To assess the effects of extracellular $\mathrm{K}^{+}$on the phosphorylation of 2-DOG, aliquots of cellular extract were separated on silica gel tlc plates, and the relative proportion of $2-\mathrm{DOG}$ and $2-\mathrm{DOG}-6-\mathrm{PO}_{4}$ was determined. The percentages of 2-DOG and $2-\mathrm{DOG}-6-\mathrm{PO}_{4}$ are shown in Table 1. Elevations in extracellular $\mathrm{K}^{+}$failed to affect the phosphorylation of transported 2-DOG.

\section{DISCUSSION}

Astrocyte-like cells have been cultured from adult human (PonteN \& MCINTYRE, 1968), fetal human (SHEIN, 1965), fetal hamster (SHEIN et al., 1970), and embryonic chick brain (BOOHER \& SENSENBRENNER, 1971). These cells have been characterized as polymorphic, with ovoid nuclei, and processes of variable
TABLE 1. RATIO BETWEen FREE AND PHOSPHORYLATED 2-DOG-EFFECT OF EXTRACELLULAR $\mathrm{K}^{+}$

\begin{tabular}{cccc}
\hline $\begin{array}{c}\mathbf{K}_{\text {out }}^{+} \\
(\mathrm{mM})\end{array}$ & $\begin{array}{c}2-\mathrm{DOG} \\
(\mathrm{mM})\end{array}$ & $\%$ Free & $\%$ Phosphorylated \\
\hline 6.9 & 0.10 & 50 & 50 \\
& 0.25 & - & 50 \\
& 0.50 & 33 & 66 \\
11.9 & 1.00 & 51 & 49 \\
& 0.10 & 50 & 50 \\
& 0.25 & 45 & 55 \\
& 0.50 & 51 & 49 \\
16.9 & 1.00 & 55 & 45 \\
& 0.10 & 51 & 49 \\
& 0.25 & 42 & 58 \\
& 0.50 & 44 & 56 \\
26.9 & 1.00 & 55 & 45 \\
& 0.10 & 45 & 55 \\
& 0.25 & 42 & 58 \\
& 0.50 & 42 & 58 \\
52.9 & 1.00 & - & 54 \\
& 0.10 & 46 & 55 \\
& 0.25 & 45 & 58 \\
& 0.50 & 42 & 74 \\
\hline
\end{tabular}

Aliquots of cell digestate were run on silica gel tlc plates, as described in Materials and Methods. The plates were stained, the spots scraped into scintillation vials and counted. Incubation for $15 \mathrm{~min}$ as in Fig. 4.

length (NAKaI \& OKamoto, 1968; LUMSDEN, 1968). Cultures derived from neonatal rat brain (CUmmins \& GLOVER, 1978) produce a population of astrocytes which evince morphological, histochemical and cytochemical characteristics similar to astrocytes in situ. These cells resemble astrocytes by the morphological criteria of Ponten \& MCINTYRE (1968), SHeIN (1965), Shein et al. (1970), NAKAI \& OKamoto (1968), MURRAY (1968) and LuMSDEN (1968). Moreover, the cultured astrocytes stain with astrocyte-specific stains, and also contain significant amounts of glycogen, a cytoplasmic constituent which Sotelo \& PALAY (1968), and PETERs et al. (1976) have demonstrated in brain astrocytes.

The control of hexose uptake in nervous tissue is not well understood. Control of hexose uptake may be more complex in brain than in other tissues due to the blood-brain barrier for hexoses (PARDRIDGE \& OLDENDORF, 1975), the multiplicity of compartments in brain (LUND-ANDERSON et al., 1976), as well as differences in the uptake properties of the constituent cell types. We chose to use $2-\mathrm{DOG}$ as a model hexose to examine the uptake of sugars by cultured astrocytes. This substance is readily taken up by brain in vivo (BIDDER, 1968; PARDRIDGE \& OldendorF, 1975), by brain slices in vitro (BACHELARD, 1971; COOKE \& RoBINSON, 1971) and by synaptosomes (Diamond \& Fishman, 1973; Heaton \& Bachelard, 1973). Furthermore, it is not metabolized in brain beyond the phosphorylation step (Sols \& CRANE, 1954; BACHELARD et al., 1971).

Of the two glucose analogs most often used to study the parameters of hexose uptake, 2-DOG 
appears to be the one most closely related to glucose in its uptake properties. 2-DOG is a competitive inhibitor of glucose uptake in brain (PARDRIDGE \& OLDENDORF, 1957), whereas glucose does not appear to compete with 3-O-methylglucose in any simple manner (CoOke \& RoBinson, 1971). Since glucose is a competitive inhibitor of 2-DOG uptake in astrocytes, we feel justified in using 2-DOG as a model for examining the regulation of glucose uptake in astrocytes.

Levels of extracellular $\mathrm{K}^{+}$in brain remain relatively constant, with extreme stimulation of neurons increasing the extracellular $\mathrm{K}^{+}$by about $6 \mathrm{~mm}$ to a final concentration of 9-12 mM (SOMJEN, 1975; SOMJEN et al., 1976). We have demonstrated that for most 2-DOG concentrations maximal 2-DOG uptake in vitro occurred at $11.9 \mathrm{~mm}-\mathrm{K}^{+}$. This finding suggests that the extracellular levels of $\mathrm{K}^{+}$in brain may be an important regulator of hexose uptake by astrocytes in situ.

Sugar uptake is $\mathrm{Na}^{+}$dependent in most mammalian tissues (KoHn \& Clausen, 1971; Schultz \& Curran, 1970). In most systems there is also a clear $\mathrm{K}^{+}$dependence of uptake processes (BIHLER \& SAWH, $1971 a, b)$ and sugar transport in excitable cells appears to be a function of both $\mathrm{K}^{+}$and $\mathrm{Na}^{+}$extracellular concentrations (RYBOVA, 1959; BHATTACHARYA, 1961). The observed $\mathrm{Na}^{+}$dependence of the astrocytic uptake of 2-DOG is in marked contrast to the $\mathrm{Na}^{+}$independent hexose uptake reported for whole brain (PARdridge \& OldendorF, 1975; LundANDERSON et al., 1976).

The results presented here indicate that astrocytes are closely attuned to the metabolism of neurons, and that astrocyte metabolism may be regulated by one aspect of neuronal activity, the level of extracellular $\mathrm{K}^{+}$

\section{REFERENCES}

Antanitus D., Choi, B. \& Lapham L. (1975) Immunofluorescent staining of astrocytes in vitro using antiserum to glial fibrillary acidic protein. Brain Res. 89, 363-367.

BACHELARD H. (1971) Specificity and kinetic properties of monosaccharide uptake into guinea pig cerebral cortex in vitro. J. Neurochem. 18, 213-222.

BaChelard H., Clark A. \& Thompson M. (1971) Cerebral cortex hexokinases: elucidation of reaction mechanisms by substrate and dead-end inhibitor kinetic analysis. Biochem. J. 123, 707-715.

Balazs R. (1970) Carbohydrate metabolism, in Handbook of Neurochemistry (LAJTHA A., ed.) Vol. 3, pp. 1-36. Plenum Press, London.

Betz A. \& Gilboe D. (1974) Kinetics of cerebral glucose transport in vivo: inhibition of 3-O-methyl glucose. Brain Res. 65, 368-372.

Bhattacharya G. (1961) Effects of metal ions on the utilization of glucose and on the influence of insulin on it by the isolated rat diaphragm. Biochem. J. 79, 369-377.

BIDDER T. G. (1968) Hexose translocation across the brain interface: configurational aspects. $J$. Neurochem. 15, 867-874.
BiHLer I. \& SAWH P. (1971a) Regulation of sugar transport in muscle: effect of increased external potassium. Biochim. biophys. Acta 241, 302-309.

BiHLer I. \& SAWH P. (1971b) Effects of diphenylhydantoin on the transport of $\mathrm{Na}^{+}$and $\mathrm{K}^{+}$and the regulation of sugar transport in muscle in vitro. Biochim. biophys. Acta 249, 240-251.

Block R., Durrum E. \& Zweig G. (1958) Paper Chromatography and Paper Electrophoresis. Academic Press, New York.

BoOHER J. \& SENSENBRenNer M. (1971) Growth and cultivation of dissociated neurons and glia cells from embryonic chick, rat and human brain in flask cultures. Neurobiology 2, 97-105.

Clausen T. (1965) The relationship between the transport of glucose and cations across cell membranes in isolated tissues-I. Biochim. biophys. Acta 109, 164-176.

Clausen T. (1966) The relationship between the transport of glucose and cations across cell membranes in isolated tissues-II. Effects of $\mathrm{K}^{+}$-free medium, ouabain and insulin upon the fate of glucose in rat diaphragm. Biochim. biophys. Acta 120, 361-368.

Clausen T. (1969) Relationship between transport of glucose and cations across cell membranes in isolated tissues--V. Stimulating effect of ouabain, $\mathbf{K}^{+}$-free medium, and insulin on effect of 3-O-methylglucose for epididymal adipose tissue. Biochim. biophys. Acta 183, 625-634.

CoOke W. \& RoBinson J. (1971) On the uptake of hexoses by rat cerebral cortical slices. J. Neurochem. 18, 1351-1356.

Cummins C. J. \& Glover R. A. (1978) Propagation and histological characterization of a homotypic population of astrocytes derived from neonatal rat brain. $J$. Anat. 125, 117-125.

Diamond I. \& Fishman R. (1973) High affinity transport of 2-deoxy-D-glucose in isolated synaptic nerve-endings. Nature, Lond. 242, 122-123.

Gilman A. \& NiRENberg M. (1971) Effect of catecholamines on the adenosine $3^{\prime}: 5^{\prime}$-cyclic monophosphate concentrations of clonal satellite cells of neurons. Proc. natn. Acad. Sci. U.S.A. 68, 2165-2168.

Heaton G. \& Bachelard H. (1973) The kinetic properties of hexose transport into synaptosomes from guinea-pig cerebral cortex. J. Neurochem. 21, 1099-1108.

HerTz L. (1966) Neuroglial localization of potassium and sodium effects on respiration in brain. $J$. Neurochem. 13, 1373-1387.

HERTZ L. (1973a) Ion Effects in Metabolism in the Adult Mammalian Brain. Fadls Forlag, Copenhagen.

HerTZ L. (1973b) Potassium ion homeostasis in the cerebral cortex. Biochem. Soc. Trans. 1, 115-118.

Hertz L. \& Clausen T. (1963) Effects of potassium and sodium on respiration: their specificity to slices from certain brain regions. Biochem. J. 89, 526-533.

Horton R., Meldrum B. \& Bachelard H. (1973) Enzymic and cerebral metabolic effects of 2-deoxy-D-glucose. $J$. Neurochem. 21, 507-520.

KeTY S. (1957) The general metabolism of the brain in vivo, in Metabolism of the Nervous System (Richter D., ed.) pp. 221-237. Pergamon Press, London.

Kletzien R. \& Purdue J. (1974) Sugar transport in chick embryo fibroblasts-1. J. biol. Chem. 249, 3366-3374.

Kohn P. \& Clausen T. (1971) The relationship between the transport of glucose and cations across cell membranes in isolated tissues-VII. Biochim. biophys. Acta 255, 798-814. 
Lowry O. H., Rosebrough N. J., FarR A. L. \& Randall R. J. (1951) Protein measurement with the Folin phenol reagent. J. biol. Chem. 193, 265-275.

LUMSDEN C. (1968) Nervous tissues in culture, in Structure and Function of the Nervous System (BOURNE G., ed.). Academic Press, New York.

Lund-Anderson H., Kjeldsen C., Hertz L. \& Brondsted H. (1976) Uptake of glucose analogues by rat brain cortex slices: $\mathrm{Na}^{+}$independent membrane transport. $J$. Neurochem. 27, 369-373.

Maker H., Clarke D. \& Lajtha A. (1976) Intermediary metabolism of carbohydrates and amino acids, in Basic Neurochemistry (Siegel G., Albers W., Katzman R. \& AgRanoff B., eds.), pp. 279-308. Little, Brown, Boston.

McIlwain H. (1951) Glutamic acid and glucose as substrates for mammalian brain. J. ment. Sci. 97, 674-680.

MCILWAIN H. (1953) Substances which support respiration and metabolic response to electrical impulses in human cerebral tissues. J. Neurol. Neurosurg. Psychiat. 16, 257-266.

MCMORRIS F. A. (1977) Norepinephrine induces glialspecific enzyme activity in cultured glioma cells. Proc. natn. Acad. Sci. U.S.A. 74, 4501-4504.

Murray M. (1968) Nervous tissue in vitro, in Cells and Tissues in Culture (WILMER E., ed.) pp. 373-456. Academic Press, New York.

NAKAl J. \& OKAMOTO M. (1968) Identification of neuroglial cells in tissue culture, in Morphology of the Neuroglia (NaKaI J., ed) pp. 65-102. Igaka Shoin, Tokyo.

NEWBURGH R. \& RoSENBERG R. (1972) Effect of norephinephrine on glucose metabolism in glioblastoma and neuroblastoma cells in culture. Proc. natn Acad. Sci. U.S.A. 69, 1677-1680.

PARDRIDGE W. \& OLDENDORF W. (1975) Kinetics of bloodbrain barrier transport of hexoses. Biochim. biophys. Acta 382, 377-392

Peters A., Palay S. \& Webster H. deF. (1976) The Fine Structure of the Nervous System: The Neurons and Supporting Cells. Saunders, Philadelphia.

Peters A. \& Palay S. (1965) An electron microscopic study of the distribution and pattern of astroglial processes in central nervous system. J. Anat. 99, 419-423.

Ponten J. \& McInTYRe E. (1968) Long term culture of normal and neoplastic human glia. Acta path. microbiol. scand. 74, 465-486.

Renner E., Plagemann P. \& Bernlohr R. (1972) Permeation of glucose by simple and facilitated diffusion by Novikoff rat hepatoma cells in suspension culture and its relationship to glucose metabolism. J. biol. Chem. 247, 5765-5776.

Rolleston F. \& Newsholme E. (1967) Control of glycolysis in cerebral cortex slices. Biochem. J. 104, 524-533.

Rybova R. (1959) The effects of cations on ammonia accumulation in. brain cortex. J. Neurochem. 4, 304-306.

SANDRA A. \& Przybylski R. (1975) 2-Deoxy-D-glucose uptake in developing chick skeletal muscle in vitro. Trans. Am. Soc. Cell Biol. 15, 381.

Schultz S. \& CuRraN P. (1970) Coupled transport of sodium and organic solutes. Physiol. Rev. 50, 637-718.

Sefton B. \& Rubin H. (1971) Stimulation of glucose transport cultures of density inhibited chick embryo cells. Proc. natn. Acad. Sci. U.S.A. 68, 3154-3157.

SHEIN H. (1965) Propagation of human fetal spongioblasts and astrocytes in dispersed cell cultures. Expl. Cell Res. 40, 554-569.

Shein H., Britva A., Hess H. \& Selkoe D. (1970) Isolation of hamster brain astroglia by in vitro cultivation and subcutaneous growth, and content of cerebroside, ganglioside, RNA and DNA. Brain Res. 19, 497-501.

Sols A. \& CRANE R. (1954) Substrate specificity of brain hexokinase. J. biol. Chem. 210, 581-595.

SOMJEN G. (1975) Electrophysiology of neuroglia. A. Rev. Physiol. 37, 163-190.

Somen G., Rosenthal M., Cordingley G., Lamanna J. \& Lothman E. (1976) Potassium, neuroglia, and oxidative metabolism in central gray matter. Fedn Proc. Fedn Am. Socs exp. Biol. 35, 1266-1271.

Sotelo C. \& Palay S. (1968) The fine structure of the lateral vestibular nucleus in the rat--I. Neurons and neuroglia. J. Cell Biol. 36, 151-179. 